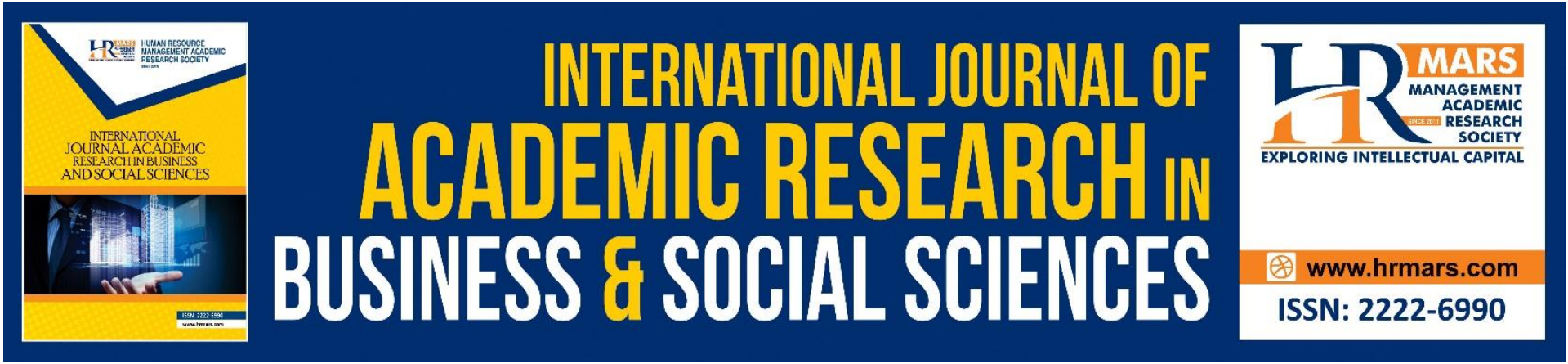

\title{
Importance of Managerial Roles and Capabilities on Organizational Effectiveness
}

\section{Shekh Mohammed Dler, Akam Omar Tawfeq}

To Link this Article: http://dx.doi.org/10.6007/IJARBSS/v11-i4/9748

DOI:10.6007/IJARBSS/v11-i4/9748

Received: 19 February 2021, Revised: 23 March 2021, Accepted: 15 April 2021

Published Online: 28 April 2021

In-Text Citation: (Dler \& Tawfeq, 2021)

To Cite this Article: Dler, S. M., \& Tawfeq, A. O. (2021). Importance of Managerial Roles and Capabilities on Organizational Effectiveness. International Journal of Academic Research in Business and Social Sciences, 11(4), 957-964.

\section{Copyright: (c) 2021 The Author(s)}

Published by Human Resource Management Academic Research Society (www.hrmars.com)

This article is published under the Creative Commons Attribution (CC BY 4.0) license. Anyone may reproduce, distribute, translate and create derivative works of this article (for both commercial and non-commercial purposes), subject to full attribution to the original publication and authors. The full terms of this license may be seen at: http://creativecommons.org/licences/by/4.0/legalcode

Vol. 11, No. 4, 2021, Pg. 957 - 964

Full Terms \& Conditions of access and use can be found at http://hrmars.com/index.php/pages/detail/publication-ethics 


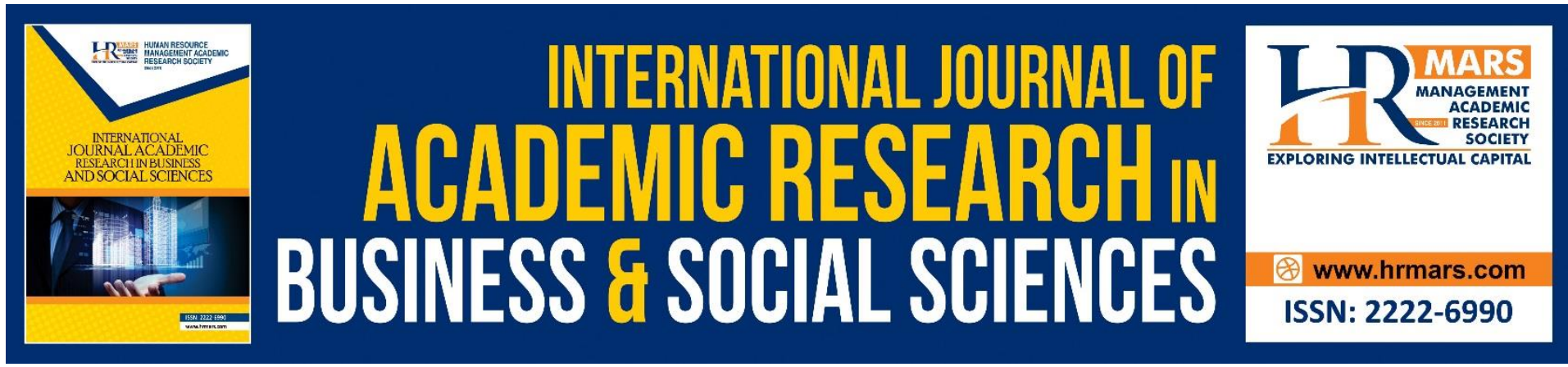

\title{
Importance of Managerial Roles and Capabilities on Organizational Effectiveness
}

\author{
Shekh Mohammed Dler, Akam Omar Tawfeq \\ Tishk International University, Sulaymaniyah Campus, Iraq \\ Business and Management Department \\ Email: shekhmuhammad01@gmail.com, akam.omer9@gmail.com
}

\begin{abstract}
Managerial capabilities and perceptions have positive impact on their success. Aim of the current study is to understand and evaluate the perception of the Kurdish managers in the Sulaymaniyah city. Accordingly, it has been a face to face interview programmed and the managers of various companies have been visited. During the interviews, we have asked several questions based on the managerial roles and capabilities. In conclusion, ten companies have been visited and related managers have been interviewed. As a result, it has been observed that residential managers give the most importance on "Creating an innovative culture" in the organization. Secondly, they have noted that "time management" has vitally important role in the managers daily activities.

Keywords: Managerial Capabilities, Managerial Skills, Management Functions, Kurdistan, Real Market Project
\end{abstract}

\section{Introduction}

According to current literature, one of the pioneer leadership studies have emerged with Ohio state university leadership studies in 1945 by Hemphill, Stogdill, Coons, Fleishman, Harris, and Burtt (Warrick, 1981). These scholars noted that leaders have two main behaviors in the organizations. These are Consideration and Structural concentration. Consideration involves two-way communication between leaders and followers, which constructed on trust, awareness of followers needs, mutual respect and understanding. Hence, structural behaviors are leaders' formal duties and instructions according to objectives, which comprise planning, assigning tasks among employees, role descriptions, scheduling, and following production (Schriesheim and Bird, 1979; Shartle, 1979).

Further, current literature noted that Great Man, Trait, Behavioral, Situational and Contingency theories are the other approaches of the scholars in the history that tried to explain leader's success on the employee motivation, organizational success or the environment that affects the leader's success for the organizational efficiency respectively (Budur, 2018; Serin, 2017).

On the other hand, employee performance is another factor that scholars argued throughout the history that how extent it is influential on the organizational effectiveness (Budur and Poturak, 2021; Mohammed et al., 2020; Top et al., 2020). Michlitsch (2000) noted that 
employee performance is one of the most important factors on the long-term organizational effectiveness. According to him, factors that affect employee performance and organizational success are mission and strategy, selection and training, company culture, communication and information, and rewards.

Furthermore, current literature revealed that organizations should have some social activities and objectives beside financial goals in the market (Budur and Demir, 2019). It has been noted that these social orientations of company have some advantageous such as increased customer awareness in the market, increased employee satisfaction, and decreased advertisement costs for the firm (Rashid et al., 2020; Torlak et al, 2019). In this respect, social responsibility of business refers to decisions and activities that aims to leverage the welfare of the society (Ali and Yildiz, 2020; Budur, 2020). Consequently, these businesses operate in such a way that they accomplish social gains (social output) along with the traditional economic gains (economic output) in which the business firm is interested.

In this respect, current paper aims to investigate some of important managerial functions at the companies in Kurdistan region of Iraq. Based on our observations, employees and managers in the region cannot use their abilities to transform into constructive outcomes in terms of employee motivation or increased performance and positive customer handlings and customer satisfaction. In line with the Introduction to Management course, it has been proposed that managerial functions and behaviors might positively increase the internal effectiveness of the company that in turn leverage employee satisfaction and customer satisfaction. Accordingly, some of the managerial functions have been conceptualized and asked to the managers of the companies through interviews. In the following sections, managerial functions have been explained and the responses of the managers demonstrated respectively.

\section{Literature}

Effective management is described as reaching organizational objectives through people and resources (Certo, 2000; Torlak et al., 2021). To reach desired objectives, managers have to use mainly some tools within the organization, which are planning, organizing, leading, motivation, and controlling (Certo, 2000; Daft, 2013). Scholars noted that these functions of management help administrators to organize and follow their responsibilities appropriately. However, the importance of these functions could vary from organization to another based on their objectives and sectors (Altun, 2017; Serin, 2018; Yildiz, 2017).

Accordingly, planning helps managers to define organizational objectives at the beginning of the business and gives the chance to illustrate some strategic steps based on the alternatives according to environment of the company (Daft, 2013). Besides, organizing involves defining the resources and authorities of the company and their possible sharing among the responsible units and employees in the firm based on the objectives (Robbins \& Coulter, 2007; Sherwani, 2014). Further, motivation and leading functions of management covers inspiration of a leader to motivate organizational members to reach their goals even to go beyond their responsibilities (Demir et al., 2021; Poturak et al, 2020). And Lastly, controlling is the evaluation process of the company based on the objectives of the units to check their position according to defined performances to require related regulations (Celik and Yildiz, 2017; Certo, 2000; Robbins, 2007).

Apart from these useful dimensions of management, scholars investigated some more competencies to increase the effectiveness of managers on the organizational success. These are decision making styles (Demir and Bulut, 2019), communication (Top et al., 2020), 
teamwork and understanding (Morgeson \& DeRue, 2006), trust in team members (Budur, 2018), time management (Hackworth, 2008).

Furthermore, it has been defined the profit of an effective manager for a company is utmost important. Some of their contributions are as followed.

- Managers facilitate goal attainment; they help subordinates to understand objectives of the company and collaborate to reach individual and group objectives (Budur and Demir, 2019).

- Managers increase the efficiency; they can see the conceptual picture appropriately and divide the limited resources of the economy to their suitable places. So that, they can decrease the waste and costs of the company (Sahin, 2014; Yildiz and Amin, 2020).

- Managers adapt organization to environment; the environment is a fast-changing factor of a company that have direct and indirect impact on the activities of the organization. From this point of view, they help organization to have up to data information and provide related trainings to follow environmental changes (Budur and Demir, 2019b).

- Managers who has ethical values are one of the indicators of societal developments. For inside of the company and for the outside of the company, it means for employees and customers they provide fair management and quality services or products that aim to leverage the quality of the life (Kavlu, 2017; Zaim et al., 2020).

- Effective managers use their and others time appropriately that they can transform it into useful asset for the profit of the organization (Yildiz, 2015).

- They can decrease the conflicts or inconveniences through their experiences easily (Koran \& Koran, 2017; Demir and Budur, 2019).

- They provide a trustable atmosphere within the organization that everyone can visit them easily for any kind of problems (Altun, 2019; Budur and Poturak, 2020).

\section{Effective Managerial Skills in Kurdistan}

"It's not about money. It's about the people you have, and how you're led." - Steve Jobs

All organizations exist for certain purposes or targets, and managers are answerable for merging and using organizational recourses to ensure that their organizations achieve their objectives. Management act as a monitor to a group of people working in the organization and harmonizing their works, toward the achievement mutual objective (Certo, 2000; Torlak et al., 2021).

Further, management process contains mainly four primary tasks to be accomplished: planning, organizing, leading, and controlling. It is significant to recognize that the management process is not always straight. As the management development advances, transformations and alterations based on the environmental fluctuations. So that managers make sure the necessary changes are affected and that the unity and integrity of the entire process is supported (Opatha, 2013).

Following these further, planning refers to definition of the goals for the organization and determining what actions and resources are needed to attain the goals. It is concerned with organizational success in short and long term. Throughout planning, management expresses what the future of the organization should be and related resources to reach that point. It is essential to getting the "right" things done (Certo, 2003). Tactical plans are long-term and affect the whole organization. A tactical plan connection the gap between what an organization is and what it will become. Tactical plans translate strategic plans into particular 
actions that need to be implemented by subdivisions throughout the organization (Certo \& Peter, 1993).

Once plans are created, decisions must be generated to find best implementations of the plans. The plans that are created should be adaptable and flexible. The organizing function engages choosing how the organization will be regulated (by departments, carrier teams, job responsibilities, etc.). Hence, organizing involves allocating authority and responsibility to numerous departments, distributing resources across the organization, and defining how the activities of groups and characters will be synchronized (Certo, 2018).

Approximately everything that is accomplished in an organization is completed by individuals. The best planning and organizing will not be effective if the people in the organization are not whole-hearted to support the plan. It can be defined as, guiding the activities of organization members in appropriate directions. Leaders use knowledge, personality, and charisma to produce passion and motivate effort to achieve targets (Certo \& Peter, 1993). Managers must also lead by interconnecting goals throughout the organization, by constructing commitment to a mutual concept, by building distributed ethics and culture, and by inspiring high routine. Managers can use the power of reward and punishment to make individuals encouragement plans and goals. Leaders stimulate people to support plans, creating faith and commitment (Certo, 2018). Leadership and management abilities are not identical, although they can materialize in the most effective people. Accordingly, ultimate purpose of leading is to increase the productivity.

Detecting and responding to what essentially happens is termed controlling. Controlling is the process of observing activities, evaluating performance, associating results to objectives, and making modifications and improvements when needed, process of collecting data, providing reward and punishment. This is frequently labelled as a feedback ring, as shown in the illustration of a product strategy feedback ring. It is a repeating process, means that is not for onetime to be used (Opatha, 2013).

Following the management functions, administrative members required to have some certain skills or abilities to carry out the process of reaching organizational goals by working with and through people and other organizational resources. Management skills can be almost anything that enables one to manage others effectively.

Human skills the ability to work with, understand and motivate others, build the cooperation within the team being led. This ability requires to work with attitudes and behaviors to effective communication, whereas individual and group interest important at all three management levels, which are top management, middle lever management and first-line management. Managers who can motivate their workforce are true property to their business. This type of interface not only increases productivity and employee fulfillment, but it sets a good example as well (Pant \& Baroudi, 2008).

Technical skills refer to ability to use relevant tools and techniques, specialized knowledge, and skills. Mostly related to working with "thing" process or physical object. Technical skills are more significant for low-level managers than for those at the top of the responsibility line. Many companies encourage their managers to have superficial knowledge about the stuff that the departments use to understand the needs of the functional resources (Anastakis et al., 1999).

Conceptual skill involves the understanding of an organization as whole. The mental ability to analyze and diagnose complex situations. It's hard to get the big picture when supervisors have a narrow perception. So that effective managers are deeply involved in the interpersonal relationships like working in a series of opera concerts. It's significant for managers to 
understand the work of the company and to navigate interpersonal interaction cleverly (Moore \& Rudd, 2005).

\section{Conclusion}

Based on these explanations and definitions about the managerial functions and capabilities, current study aimed to understand and evaluate the perception of the Kurdish managers in the Sulaymaniyah city. Accordingly, it has been a face to face interview programmed and the managers of various companies have been visited. During the interviews, we have asked several questions based on the managerial roles and capabilities. In conclusion, ten companies have been visited and related managers have been interviewed. As a result, it has been observed that residential managers give the most importance on "Creating an innovative culture" in the organization. Secondly, they have noted that "time management" has vitally important role in the managers daily activities. Thirdly, administrative of the companies perceive that "effective communication" has positive impact on their success. And lastly, "decision making" another important capability of the managers to reach objectives.

\section{Contribution of the Study}

According to the results of the study, residential manager gives more importance on establishing an innovative culture in the organization. Secondly, they want to use their time effectively to reach organizational goals. In this respect, if they receive suitable trainings and provide such kinds of trainings to their staff, it can have significant impact on their success. Further, managers in the region should have active HR departments to provide further training programs based on the requirements of the market.

\section{Future Research and Limitations}

Study aimed to investigate important managerial roles in the Kurdistan Region of Iraq. However, the research was limited with the Kurdish companies. Other drawbacks of the study were time that managers do not have enough time for increasing the number of the studies and having more practical information. Lastly, future studies should prepare some similar questions for a greater number of firms to reach more reliable results.

\section{References}

Ali, S. H., \& Yildiz, Y. (2020). Leadership effects on CSR employee, media, customer, and NGOs. Manag Econ Res J, 6(2020), 12354.

Altun, M. (2017). The effects of teacher commitment on student achievement. International Journal of Social Sciences \& Educational Studies, 3(3), 51.

Altun, M. (2019). An Underestimated Tool: Body Language in Classroom during Teaching and Learning. International Journal of Social Sciences \& Educational Studies, 6(1), 155.

Anastakis, D. J., Regehr, G., Reznick, R. K., Cusimano, M., Murnaghan, J., Brown, M., \& Hutchison, C. (1999). Assessment of technical skills transfer from the bench training model to the human model. The American journal of surgery, 177(2), 167-170.

Budur, T. (2018). The impact of Al-Ghazali's virtues on organizational commitment and performance: A case Study at private education institutions in Kurdistan Region of Iraq. Icabep, Erbil-Iraq, 2, p21.

Budur, T., \& Demir, A. (2019). Leadership effects on employee perception about CSR in Kurdistan Region of Iraq. International Journal of Social Sciences \& Educational Studies, 6(1). 142-154. 
Budur, T., \& Poturak, M. (2020). Transformational leadership and its impact on customer satisfaction. Measuring mediating effects of organisational citizenship behaviours. Middle East Journal of Management, 8(1), 67-91.

Budur, T., \& Poturak, M. (2021). Employee Performance and Customer Loyalty: Mediation effect of Customer Satisfaction. Middle East Journal of Management.

Budur, T., \& Poturak, M., (2020). Transformational Leadership and its Impact on Customer Satisfaction. Measuring Mediating Effects of Organizational Citizenship Behaviors. Middle East Journal of Management.

Budur, T. (2020). Impact of Transformational Leadership on Customer Satisfaction: Mediating effects of Employee Performance and Organizational Citizenship Behaviors. (Unpublished doctoral dissertation). International Burch University.

Celik, B., \& Yildiz, Y. (2017). Commitment to the teaching profession. International Journal of Social Sciences \& Educational Studies, 4(2), 93-97.

Certo, F. (2018). Technological innovations in multimodal management of glioblastoma: from nano-drugs to imaging guided surgery and supra-maximal resection.

Certo, S. C. (2000). Modern management: diversity, quality, ethics \& the global environment.

Certo, S. C. (2003). Modern management: adding digital focus. Prentice Hall.

Certo, S. C., \& Peter, J. P. (1993). Strategic management: A focus on process. McGrawHill/Irwin.

Daft, R. L. (2013). Management. Cengage Learning.

Demir A, Shawkat S, Majeed BN, Budur T. (2019). Fuzzy AHP and VIKOR to select best location for bank investment: case study in Kurdistan Region of Iraq. In Effective Investments on Capital Markets, Tarczyn'sk W, Nermend K (eds). Springer: Cham; 485-510.

Demir, A., \& Budur, T. (2019). Roles of leadership styles in corporate social responsibility to non-governmental organizations (NGOs). International Journal of Social Sciences \& Educational Studies, 5(4), 174-183.

Demir, A., \& Bulut, I. (2018). A New Model for Respected Meetings. Procedia Computer Science, 126, 1637-1655.

Demir, A., Budur, T., \& Heshmati, A. (2020). Antecedents of trust, corporate image, and switching costs: A case in telecommunication services in Kurdistan Region of Iraq. International Journal of Mobile Communications.

Demir, A., Budur, T., Hiwa, M., \& Heshmati, A. (2021). Links between Knowledge Management and Organizational Sustainability: Does the ISO 9001 certification have an effect? Knowledge Management Research \& Practice (TKMR), Doi: $10.1080 / 14778238.2020 .1860663$

Hackworth, T. (2008). Time management for the nurse leader. Nursing2019 Critical Care, 3(2), 10-11.

Kavlu, A. (2017). Implementation of Project-Based Learning (PBL) in EFL (English as a Foreign Language) classrooms in Fezalar Educational Institutions (Iraq). In 5th International Research Conference on Education, May 1-2, Tbilisi, Georgia.

Koran, S., \& Koran, E. (2017). Principals' Leadership Styles and Strategies Employed to Motivate Teachers in Ronaki Hawler Educational Institutions, Erbil, Iraq. International Journal of Social Sciences \& Educational Studies, 4(3), 146-159.

Mohammed, S. S., Suleyman, C., \& Taylan, B. (2020). Burnout Determinants and Consequences Among University Lecturers. Amazonia Investiga, 9(27), 13-24.

Moore, L. L., \& Rudd, R. D. (2005). Extension leaders' self-evaluation of leadership skill areas. Journal of Agricultural Education, 46(1), 68-78. 
Morgeson, F. P., \& DeRue, D. S. (2006). Event criticality, urgency, and duration: Understanding how events disrupt teams and influence team leader intervention. The Leadership Quarterly, 17(3), 271-287.

Opatha, H. H. D. N. P. (2013). Green human resource management a simplified introduction.

Pant, I., \& Baroudi, B. (2008). Project management education: The human skills imperative. International journal of project management, 26(2), 124-128.

Poturak, M., Mekić, E., Hadžiahmetović, N., \& Budur, T. (2020). Effectiveness of Transformational Leadership among Different Cultures. International Journal of Social Sciences \& Educational Studies, 7(3), 119-129.

Rashid, C. A., Salih, H. A., \& Budur, T. (2020). The Role of Online Teaching Tools on the Perception of the Students during the Lockdown of Covid-19. International Journal of Social Sciences \& Educational Studies, 7(3), 178-190.

Robbins, S. P., \& Coulter, M. (2007). Principles of management. Translated by Seyyed Mohammad Arabi and Mohammed Ali Hamid Rafiee and Behrouz Asrari Ershad, Fourth Edition, Tehran: Office of Cultural Studies.

Sahin, O. (2014). An investigation of student satisfaction factors. Journal of Research in Business and Management, 2(6), 8-1.

Serin, H. (2018). The use of extrinsic and intrinsic motivations to enhance student achievement in educational settings. International Journal of Social Sciences \& Educational Studies, 5(1), 191-194.

Serin, H. (2017). Developing the teaching profession: factors influencing teachers' performance. International Journal of Social Sciences \& Educational Studies, 4(2), 10-14.

Sherwani, K. H. (2014). Development of Performance Management Concept in Higher Education Context. International Journal of Social Sciences \& Educational Studies, 1(2), 46.

Top, C., Abdullah, B. M. S., \& Faraj, A. H. M. (2020). Transformational Leadership Impact on Employees Performance.

Torlak, N. G., Demir, A., \& Budur, T. (2019). Impact of operations management strategies on customer satisfaction and behavioral intentions at café-restaurants. International Journal of Productivity and Performance Management. Vol. 69 No. 9, pp. 1903-1924.

Torlak, N. G., Demir, A., \& Budur, T. (2021). Decision-making, leadership and performance links in private education institutes. Rajagiri Management Journal. Doi:10.1108/RAMJ10-2020-0061.

Yildiz, Y. (2015). Better Education at Ishik University Preparatory School with Extracurricular Activities. Advances in Language and Literary Studies, 6(4), 158-161.

Yildiz, Y. (2017). Components of Commitment to the Teaching Profession. International Journal of Social Sciences \& Educational Studies, 4(2), 115.

Yildiz, Y., \& Budur, T. (2019). Introducing Environmental Awareness to College Students with Curricular and Extracurricular Activities. International journal of Academic Research in business and Social Sciences, 9(3)667-675.

Zaim, H., Demir, A., \& Budur, T. (2021). Ethical leadership, effectiveness and team performance: An Islamic perspective. Middle East Journal of Management, 8(1), 42-66. 